\title{
Effect of Ultrasonic Pretreatment on Biomethane Potential of Two-Phase Olive Mill Solid Waste: Kinetic Approach and Process Performance
}

\author{
B. Rincón, ${ }^{1}$ L. Bujalance, ${ }^{1}$ F. G. Fermoso, ${ }^{1}$ A. Martín, ${ }^{2}$ and R. Borja ${ }^{1}$ \\ ${ }^{1}$ Instituto de la Grasa (CSIC), Avenida Padre García Tejero, 4.41012 Sevilla, Spain \\ ${ }^{2}$ Departamento de Ingeniería Química y Química Inorgánica, Facultad de Ciencias, Universidad de Córdoba, \\ Campus Universitario de Rabanales, Edificio C-3, Carretera Madrid-Cádiz, km 396, 14071 Córdoba, Spain
}

Correspondence should be addressed to B. Rincón; brlloren@cica.es

Received 17 February 2014; Revised 23 July 2014; Accepted 23 July 2014; Published 12 August 2014

Academic Editor: Rafael Clemente

Copyright (C 2014 B. Rincón et al. This is an open access article distributed under the Creative Commons Attribution License, which permits unrestricted use, distribution, and reproduction in any medium, provided the original work is properly cited.

The effect of ultrasound (US) pretreatment on two-phase olive mil solid waste (OMSW) composition and subsequent anaerobic biodegradation was evaluated by chemical oxygen demand solubilization and biochemical methane potential (BMP) tests. OMSW was ultrasonically pretreated at a power of $200 \mathrm{~W}$ and frequency of $24 \mathrm{kHz}$ for time periods of 20, 40,60,90, 120, and 180 minutes, corresponding to specific energies of $11367,21121,34072,51284,68557$, and $106003 \mathrm{~kJ} / \mathrm{kg}$ total solids, respectively. In order to evaluate the US pretreatment, a low, medium, and high exposure time, that is, 20, 90, and $180 \mathrm{~min}$, were selected for BMP tests. Methane yields of $311 \pm 15,393 \pm 14$, and $370 \pm 20 \mathrm{~mL} \mathrm{CH}_{4} / \mathrm{g} \mathrm{VS}_{\text {added }}$ (VS: volatile solids) were obtained for 20, 90, and 180 minutes, respectively, while the untreated OMSW gave $373 \pm 4 \mathrm{~mL} \mathrm{CH}_{4} / \mathrm{g} \mathrm{VS}_{\text {added }}$. From a kinetic point of view, the BMP tests showed a first exponential stage and a second sigmoidal stage. In the first stage, the kinetic constant obtained for US pretreated OMSW at 20 minutes was $46 \%$ higher than those achieved for the pretreated OMSW at 90 and 180 minutes and 48\% higher than that for untreated OMSW. The maximum methane production rate achieved was $12 \%$ higher than that obtained for untreated OMSW.

\section{Introduction}

The two-phase olive mill solid waste (OMSW) is the main waste produced after primary centrifugation in the two-phase olive oil mills. In the two-phase olive oil manufacturing process a horizontally mounted centrifuge is used for primary separation of the olive oil fraction from the vegetable solid material and vegetation water. The resultant olive oil is further washed to remove residual impurities before finally being separated from this wash water in a vertical centrifuge. Therefore, the two-phase olive mills produce three waste streams: wash waters from the initial cleaning of the fruit, an aqueous solid residue called OMSW, and the wash waters generated during the purification of the virgin olive oil [1]. Two-phase OMSW is the main waste produced and has a high organic matter concentration. It is also a very wet waste (60-70\% humidity), containing $3 \%$ of olive oil and a complex structure formed mainly by lignin (42.6\%), cellulose (19.4\%), and hemicellulose (35.1\%) [2]. These characteristics result in an elevated polluting load. In addition, the quantities of OMSW generated are very large; every year from two to four million tonnes are produced in countries like Spain. Both composition and quantity produced make two-phase OMSW an important environmental problem [3].

Anaerobic digestion of solid wastes is an attractive and established option for solid wastes treatment due to the excellent waste stabilization and high energy recovery [4-7]. The feasibility of the anaerobic digestion of the two-phase OMSW has been already shown $[3,5,6]$. Methane yield coefficients up to $0.244 \mathrm{~L} \mathrm{CH}_{4} / \mathrm{g} \mathrm{COD}_{\text {removed }}$ were reported [5].

Pretreatments to break complex structures could be a good option to increase the methane yields obtained through anaerobic digestion. Among the most studied pretreatments 
to improve the hydrolysis and solubilization of complex substrates prior to their anaerobic digestion stands out the use of ultrasounds [8-14]. Ultrasonic pretreatment consists of the application of cyclic sound pressure with a variable frequency to some wastes to disintegrate rigid structures and complex compounds $[9,10]$. The chemistry of sonication as a pretreatment tool is quite complex and consists of a combination of shearing, chemical reactions with radicals, pyrolysis, and combustion [13]. During sonication, microbubbles are formed because of high-pressure applications to liquid, which cause violent collapses and high amounts of energy to be released into a small area. Consequently, because of extreme local conditions certain radicals $(\bullet \mathrm{HO}, \bullet \mathrm{H})$ can be formed $[15,16]$. The radical reactions can degrade volatile compounds by pyrolysis processes taking place in microbubbles [16].

This technology or pretreatment is widely used in industrial plants for WAS in the UK, USA, and Australia achieving a reduction in the volatile solids (VS) content between $30 \%$ and $50 \%$ and an increase in the biogas production between $40 \%$ and $50 \%$ [17]. Ultrasound pretreatment has been widely studied for WAS with interesting results and also for other substrates: sewage sludge [9], pulp mill wastewaters [10], hog manure [11], sludge from the pulp, and paper industry [12]. The main target of the ultrasound pretreatment is to disrupt flocks and break the cellular walls making easier the access to the intracellular material for its subsequent degradation. One of the main advantages of the ultrasound pretreatment is that the use of external chemical agents is prevented and, therefore, an increase in the effluent volume is avoided [13].

The effect of the ultrasonication pretreatment for different substrates treated subsequently by anaerobic digestion has been studied during the last years due to an increase in the biogas production and a reduction in the hydraulic retention times needed [8]. Mechanisms of ultrasonic treatment are influenced by four main factors: specific energy, ultrasonic frequency, application time, and the characteristics of the substrate. The increased percentage in biogas production as well as the methane content in the biogas of a sonicated sludge usually increases with the sonication time applied $[15,16]$.

The increase in specific methane yield is mainly due to the increase in the net surface area of the particles and solubilization of complex organic matter [13]. The increment of the sonication time can reduce the particle size of a substrate [18], but, for very high times of exposition to the ultrasound, the effect of particle size reduction might be stopped and the opposite effect is produced [19]. Initially the flocks are broken, but at high exposure times the intracellular polymeric compounds released might favour a reflocculation process $[19,20]$. This might result in negative effect for long exposure times.

The objective of this study was to evaluate the COD solubilization owing to the ultrasonication pretreatment of the two-phase OMSW at different specific energies and application times and to study the influence of this pretreatment on the methane production through biochemical methane potential (BMP) tests. A kinetic study of the different stages in the methane production was also carried out. There are no previous studies in the literature about ultrasound
TABLE 1: Main characteristics and composition of the two-phase OMSW used in the experiments.

\begin{tabular}{lc}
\hline Parameters & Values \\
\hline TS $(\mathrm{g} / \mathrm{kg})$ & $265 \pm 3$ \\
$\mathrm{VS}(\mathrm{g} / \mathrm{kg})$ & $228 \pm 2$ \\
$\mathrm{CODt}\left(\mathrm{g} \mathrm{O}_{2} / \mathrm{kg}\right)$ & $331 \pm 1$ \\
$\mathrm{CODs}\left(\mathrm{g} \mathrm{O}_{2} / \mathrm{kg}\right)$ & $143 \pm 3$ \\
$\mathrm{Ph}$ & $4.9 \pm 0.2$ \\
$\mathrm{TA}\left(\mathrm{g} \mathrm{CaCO}_{3} / \mathrm{kg}\right)$ & $2.5 \pm 0.1$ \\
$\mathrm{AN}(\mathrm{g}$ ammoniacal N/kg) & $0.3 \pm 0.0$ \\
$\mathrm{TKN}(\mathrm{g} \mathrm{Kjeldahl} \mathrm{N} / \mathrm{Kg})$ & $3.6 \pm 0.1$ \\
Hemicellulose $(\%)$ & $11.3 \pm 0.2$ \\
Cellulose $(\%)$ & $5.2 \pm 0.1$ \\
Lignin $(\%)$ & $19.7 \pm 0.4$ \\
Fat $(\%)$ & $3.8 \pm 0.3$ \\
\hline
\end{tabular}

TS: total solids; VS: volatile solids; CODt: total chemical oxygen demand; CODs: soluble chemical oxygen demand; TKN: total Kjeldahl nitrogen; AN: ammoniacal nitrogen; TA: total alkalinity.

pretreatment of this substrate before its anaerobic digestion process.

\section{Materials and Methods}

2.1. Two-Phase OMSW. The two-phase OMSW used for the experiments was collected from the Experimental Olive Oil Factory located in the "Instituto de la Grasa (CSIC)" of Sevilla, Spain. OMSW was sieved through a $2 \mathrm{~mm}$ mesh to remove olive stone pieces; all results are presented for sieved OMSW. The olive variety used was "Lechín” from Sevilla. The main characteristics and composition of the two-phase OMSW are presented in Table 1.

2.2. Ultrasound Pretreatment. Ultrasound pretreatment of two-phase OMSW was performed using ultrasonication equipment Hielscher UP200S (sonotrode Micro tip 7). A maximum power of $200 \mathrm{~W}(100 \%$ amplitude), constant working frequency of $24 \mathrm{kHz}$, and a constant ultrasound intensity of $5.3 \mathrm{~W} / \mathrm{cm}^{2}$ [21] were used. The ultrasound tip was used in open $100 \mathrm{~mL}$ Pyrex glass beakers. Ultrasound pretreatment times of 20,40,60, 90, 120, and 180 minutes were studied corresponding to six different specific energies and ultrasound densities [15] (Table 2). All the ultrasound pretreatment experiments were carried out in duplicate and the final results expressed as means.

Two-phase OMSW at 80\% (80 g two-phase OMSW: $20 \mathrm{~g}$ water) was used for all the experiments with ultrasound pretreatment and without pretreatment. Temperature was not controlled during the ultrasound pretreatment. After ultrasound pretreatment, the samples were cooled to ambient temperature.

2.3. Biochemical Methane Potential (BMP) Tests. To compare methane yields after the pretreatment, BMP tests were used. BMP tests were carried out in reactors with an effective volume of $250 \mathrm{~mL}$. Reactors were continuously stirred 
TABLE 2: Experimental conditions of specific energies and ultrasound densities applied to the two-phase OMSW used in the experiments $(80 \% \mathrm{w} / \mathrm{w})$.

\begin{tabular}{lccc}
\hline $\begin{array}{l}\text { Time } \\
(\mathrm{min})\end{array}$ & $\begin{array}{c}\text { Wet sample } \\
(\mathrm{g})\end{array}$ & $\begin{array}{c}\text { Specific energy } \\
(\mathrm{kJ} / \mathrm{kgTS})\end{array}$ & $\begin{array}{c}\text { Ultrasound density } \\
(\mathrm{W} / \mathrm{kg} \text { wet sample })\end{array}$ \\
\hline 20 & 99.6 & 11367 & 2008.2 \\
40 & 107.2 & 21121 & 1865.8 \\
60 & 99.7 & 34072 & 2006.6 \\
90 & 99.3 & 51284 & 2013.5 \\
120 & 99.1 & 68557 & 2018.8 \\
180 & 96.1 & 106003 & 2080.9 \\
\hline
\end{tabular}

at $500 \mathrm{rpm}$ and placed in a thermostatic water bath at mesophilic temperature $\left(35 \pm 2^{\circ} \mathrm{C}\right)$.

The reactors were sealed and the headspace of each flask was filled with nitrogen at the beginning of each assay. The methane produced was measured by liquid displacement passing the biogas through a $3 \mathrm{~N} \mathrm{NaOH}$ solution to capture $\mathrm{CO}_{2}$ assuming that the remaining gas was methane. The anaerobic digestion experiments were run for a period of 20 days until the accumulated gas production remained essentially unchanged; that is, on the last day production was lower than $2 \%$ of the accumulated methane produced. Each experiment was carried out in duplicate.

The inoculum used in the BMP assays was obtained from an industrial anaerobic reactor treating brewery wastewater and operating at mesophilic temperature. The characteristics of the anaerobic inoculum used were $\mathrm{pH}$ : 7.5 and VS: $22 \mathrm{~g} / \mathrm{L}$.

The inoculum to substrate ratio used was 2 on VS basis. For each flask containing $239 \mathrm{~mL}$ of inoculum (with a final concentration of $21 \mathrm{~g} \mathrm{VS} / \mathrm{L}$ ), the amount of untreated OMSW or ultrasound pretreated OMSW needed to give the required inoculum: substrate ratio was then added to each test digester. A volume of $0.239 \mathrm{~mL}$ of trace element solution was also added to each digester.

The composition of the trace elements solution was $\mathrm{FeCl}_{2} \cdot 4 \mathrm{H}_{2} \mathrm{O}, 2000 \mathrm{mg} / \mathrm{L} ; \mathrm{CoCl}_{2} \cdot 6 \mathrm{H}_{2} \mathrm{O}, 2000 \mathrm{mg} / \mathrm{L}$; $\mathrm{MnCl}_{2} \cdot 4 \mathrm{H}_{2} \mathrm{O}, 500 \mathrm{mg} / \mathrm{L} ; \mathrm{AlCl}_{3} \cdot 6 \mathrm{H}_{2} \mathrm{O}, 90 \mathrm{mg} / \mathrm{L} ; \quad\left(\mathrm{NH}_{4}\right)$ ${ }_{6} \mathrm{Mo}_{7} \mathrm{O}_{24} \cdot 4 \mathrm{H}_{2} \mathrm{O}, 50 \mathrm{mg} / \mathrm{L} ; \mathrm{H}_{3} \mathrm{BO}_{3}, \quad 50 \mathrm{mg} / \mathrm{L} ; \quad \mathrm{ZnCl}_{2}$, $50 \mathrm{mg} / \mathrm{L} ; \quad \mathrm{CuCl}_{2} \cdot 2 \mathrm{H}_{2} \mathrm{O}, \quad 38 \mathrm{mg} / \mathrm{L} ; \quad \mathrm{NiCl}_{2} \cdot 6 \mathrm{H}_{2} \mathrm{O}, \quad 50 \mathrm{mg} / \mathrm{L}$; $\mathrm{Na}_{2} \mathrm{SeO}_{3} \cdot 5 \mathrm{H}_{2} \mathrm{O}, 194 \mathrm{mg} / \mathrm{L}$; and EDTA, $1000 \mathrm{mg} / \mathrm{L}$. Two reactors with anaerobic inoculum and trace elements solution but without substrate addition were used as controls.

2.4. Analytical Methods. TS and VS were determined, according to the standard methods $2540 \mathrm{~B}$ and $2540 \mathrm{E}$, respectively [22]. Total chemical oxygen demand (CODt) was determined as described by Rincón et al. [4], while soluble chemical oxygen demand (CODs) was determined using the closed digestion and the colorimetric standard method 5220D [22]. $\mathrm{pH}$ was analysed using a $\mathrm{pH}$-meter model Crison 20 Basic. Total alkalinity (TA) was determined by $\mathrm{pH}$ titration to 4.3 [22]. Hemicellulose, cellulose, and lignin were determined according to Van Soest et al. method [23]. Total Kjeldahl nitrogen (TKN) was analysed using a method based on the
4500- $\mathrm{N}_{\text {org }} \mathrm{B}$ of standard methods [22]. Ammoniacal nitrogen was determined by distillation and titration according to the standard method $4500-\mathrm{NH}_{3} \mathrm{E}$ [22]. Fat was analyzed by the official method of the EEC number 2568/91 (European Community Official Diary, L248/1 of 05.09.1991). All the analyses were carried out in triplicate.

\section{Results and Discussion}

3.1. Influence of Ultrasound Pretreatment on the Characteristics of Two-Phase OMSW. Table 3 shows the characteristics of the two-phase OMSW after the different ultrasound pretreatments in terms of humidity, TS, VS, CODt, CODs, and COD solubilization. The degree of COD solubilization was calculated from the data of CODs measured after each pretreatment condition tested and CODt initial of the OMSW using the following equation $[24,25]$ :

$$
\text { COD solubilization }(\%)=\left(\frac{\mathrm{CODs}}{\mathrm{CODt}}\right) * 100 \text {. }
$$

Although COD solubilizationdid not show a big variation for the chosen US exposition times (Table 3), the best solubilization levels were achieved for the pretreatments at 90 and 120 min with $57 \%$ of solubilization, followed by the treatment at $20 \mathrm{~min}$ and $60 \mathrm{~min}$ with $56 \%$ and $55 \%$ of COD solubilization, respectively (Table 3 ). From the low times assayed (20,40, and $60 \mathrm{~min}), 20 \mathrm{~min}$ was the chosen time for the BMP tests, as for 40 and $60 \mathrm{~min}$ similar solubilizations were virtually achieved. For the same reason from the highest times studied $(90,120$, and $180 \mathrm{~min})$ the pretreatment at $90 \mathrm{~min}$ was selected. The pretreatment at $180 \mathrm{~min}$ was also assayed through BMP to compare the effect of a high exposure to ultrasound pretreatment. Therefore, the BMP tests were assayed for low, that is, $20 \mathrm{~min}$, medium, that is, $90 \mathrm{~min}$, and high, that is, $180 \mathrm{~min}$, exposition times.

Wang et al. [26] found for WAS that the concentration of soluble COD increased with the increase in the sonication time owing to the breakage to the flocks and the disrupting of cell walls in bacteria that released the extracellular organic compounds. Shimizu et al. [8] also evaluated the solubilization of WAS at different sonication times; they found that a minimum of 30-40 min of ultrasonication time was necessary to achieve $50 \%$ of solubilization. The efficiency of ultrasonication as a pretreatment method for hog manure and WAS prior to their anaerobic digestion has been recently evaluated at specific energies of $250-30,000 \mathrm{~kJ} / \mathrm{kg}$ TS [11]. The latter study confirmed that COD solubilisation from WAS correlated well with the more labour and time intensive degree of disintegration test. Hog manure was found to be more amenable to ultrasonication than WAS, as it took only $3000 \mathrm{~kJ} / \mathrm{kg}$ TS to cause $15 \%$ more solubilisation as compared to $25,000 \mathrm{~kJ} / \mathrm{kg}$ TS for WAS [11].

For all the tested times in the present study $(20,40,60,90$, 120 , and 180 minutes), COD solubilization slightly increased compared to the untreated sample, being for the longest time applied (180 min) and for the time of $40 \mathrm{~min}$ the lowest COD solubilization increase. Ultrasound pretreatment can affect the particle size; some studies establish a relationship between 
TABLE 3: Characteristics of the two-phase OMSW used $(80 \% \mathrm{w} / \mathrm{w})$ after different ultrasound pretreatment times and without pretreatment.

\begin{tabular}{|c|c|c|c|c|c|c|}
\hline $\begin{array}{l}\text { Time } \\
(\min )\end{array}$ & $\begin{array}{c}\text { Moisture } \\
(\%)\end{array}$ & $\begin{array}{c}\text { TS } \\
(\mathrm{g} / \mathrm{kg})\end{array}$ & $\begin{array}{c}\text { VS } \\
(\mathrm{g} / \mathrm{kg})\end{array}$ & $\begin{array}{c}\mathrm{CODt} \\
\left(\mathrm{g} \mathrm{O}_{2} / \mathrm{kg}\right)\end{array}$ & $\begin{array}{c}\text { CODs } \\
\left(\mathrm{g} \mathrm{O}_{2} / \mathrm{kg}\right)\end{array}$ & $\begin{array}{c}\text { Solubilization } \\
(\%)\end{array}$ \\
\hline Untreated OMSW & $78.8 \pm 0.2$ & $212.0 \pm 2.6$ & $182.7 \pm 2.3$ & $265.4 \pm 0.7$ & $114.7 \pm 3.2$ & 43 \\
\hline 20 & $79.9 \pm 0.2$ & $206.4 \pm 0.2$ & $177.7 \pm 1.9$ & $331.3 \pm 1.0$ & $148.3 \pm 0.2$ & 56 \\
\hline 40 & $80.8 \pm 0.1$ & $191.8 \pm 0.9$ & $164.1 \pm 0.2$ & $331.4 \pm 0.0$ & $130.9 \pm 0.0$ & 49 \\
\hline 60 & $78.6 \pm 0.4$ & $213.8 \pm 3.6$ & $181.4 \pm 5$ & $376.6 \pm 0.4$ & $146.8 \pm 0.0$ & 55 \\
\hline 90 & $78.3 \pm 0.3$ & $217.3 \pm 2.9$ & $183.8 \pm 0.0$ & $370.0 \pm 0.1$ & $151.0 \pm 0.0$ & 57 \\
\hline 120 & $79.3 \pm 0.3$ & $206.8 \pm 3.2$ & $173.3 \pm 0.0$ & $385.2 \pm 0.6$ & $150.6 \pm 0.1$ & 57 \\
\hline 180 & $77.9 \pm 0.5$ & $221.4 \pm 5$ & $188.6 \pm 7.4$ & $377.5 \pm 0.0$ & $126.1 \pm 0.0$ & 48 \\
\hline
\end{tabular}

TS: total solids; VS: volatile solids; CODt: total chemical oxygen demand; CODs: soluble chemical oxygen demand.

the increase in the sonication time and the particle size concluding that at higher exposure times higher solubilization and lower particle sizes were found, but for very long times of exposure to the ultrasound the opposite effect might be produced owing to the formation of recalcitrant compounds [9]. It has been also reported in the literature that high specific energies may induce the reagglomeration of particles, thereby shifting particle size toward higher diameters, decreasing slightly or keeping constant the solubilization levels [27]. The latter study revealed how the percentage of COD solubilization was maintained around $8 \%$ when the specific energy applied increased from 76.5 to $128.9 \mathrm{MJ} / \mathrm{kg}$ during the US pretreatment of algal biomass [27].

Other authors found that although sonication disrupted cellular matter providing a higher solubilization than without pretreatment for WAS, the solubilization resulted in soluble nonbiodegradable compounds [10]. The increase in sonication time causes more release of intracellular polymers; these biopolymers released were thought to be the glue that holds bioflocs together $[13,20]$.

Table 4 shows the hemicellulose, cellulose, and lignin contents of the ultrasound pretreated two-phase OMSWs compared to untreated OMSW. The highest increase in the hemicellulose content (31\%) was obtained for the OMSW pretreated during $90 \mathrm{~min}$. The increase in the cellulose content was evident for all the ultrasound pretreatments: $150 \%, 176 \%$, and $162 \%$ for 20,90 , and $180 \mathrm{~min}$, respectively, compared to the untreated two-phase OMSW. In the same way, an increase of $54 \%$ in the percentage of cellulose with respect to its initial content in the substrate was observed in the sunflower oil cake after sonication with a specific energy of $24.000 \mathrm{~kJ} / \mathrm{kg}$ TS [28].

3.2. Impact of Ultrasound Pretreatment on Biochemical Methane Potential. The methane yields obtained through BMP after 20 days of digestion for the ultrasound pretreatments selected were $311 \pm 15,393 \pm 14$, and $370 \pm 20 \mathrm{~mL} \mathrm{CH}_{4} / \mathrm{g}$ $\mathrm{VS}_{\text {added }}$ for pretreated OMSW during 20, 90, and $180 \mathrm{~min}$, respectively (Figures 1-3), and $373 \pm 4 \mathrm{~mL} \mathrm{CH}_{4} / \mathrm{g} \mathrm{VS}_{\text {added }}$ for OMSW without ultrasound pretreatment (Figure 4). The maximum value of methane yield was obtained after a pretreatment time of 90 minutes with a specific energy of $51284 \mathrm{~kJ} / \mathrm{kg}$ TS and this maximum value was only $5.6 \%$ higher than that obtained for untreated OMSW. Higher increments
TABLE 4: Hemicellulose, cellulose, and lignin contents for the untreated two-phase OMSW and ultrasound pretreated OMSW at 20,90 , and $180 \mathrm{~min}$.

\begin{tabular}{lccc}
\hline $\begin{array}{l}\text { Times } \\
(\mathrm{min})\end{array}$ & $\begin{array}{c}\text { Hemicellulose } \\
(\%)\end{array}$ & $\begin{array}{c}\text { Cellulose } \\
(\%)\end{array}$ & $\begin{array}{c}\text { Lignin } \\
(\%)\end{array}$ \\
\hline Untreated OMSW & $9.0 \pm 0.2$ & $4.2 \pm 0.1$ & $15.8 \pm 0.4$ \\
20 & $10.9 \pm 0.3$ & $10.5 \pm 0.5$ & $14.4 \pm 0.6$ \\
90 & $11.8 \pm 0.0$ & $11.6 \pm 0.6$ & $14.6 \pm 0.1$ \\
180 & $11.6 \pm 2.6$ & $11.0 \pm 1.2$ & $14.5 \pm 1.3$ \\
\hline
\end{tabular}

in biogas production and methane yields were reported after sonication of other substrates when compared with untreated samples. For instance, Bougrier et al. [29] showed an increase in the methane yield of WAS from 221 to $334 \mathrm{~mL} \mathrm{CH}_{4} / \mathrm{g}$ $\mathrm{COD}_{\text {added }}$ after an ultrasonic pretreatment at $9350 \mathrm{~kJ} / \mathrm{kg}$ TS, which was more effective than other pretreatments assessed such as ozonation or thermal pretreatment. In the same way, an increase in the methane production of $44 \%$ was also reported by Erden and Filibeli [30] for WAS previously sonicated with a specific energy of $9690 \mathrm{~kJ} / \mathrm{kg}$ TS. Likewise, an improvement of $16 \%$ in specific biogas production was also observed after ultrasonic pretreatment of WAS with a high content of polycyclic aromatic hydrocarbons at a specific energy of $11000 \mathrm{~kJ} / \mathrm{kg}$ TS [16]. Similarly, the methane potential of hog manure increased by $20.7 \%$ in comparison with unsonicated manure for a specific energy input of $30000 \mathrm{~kJ} / \mathrm{kg}$ TS [11], which is lower than that used in the present work for obtaining the maximum methane yield $(51284 \mathrm{~kJ} / \mathrm{kg}$ TS).

In the present study, methane yield slightly increased when the pretreatment time was increased from 20 to 90 minutes and the specific energy consequently increased from 11367 to $51284 \mathrm{~kJ} / \mathrm{kg}$ TS. A slight decrease in the methane yield was observed for an exposure time of 180 minutes with a specific energy of $106003 \mathrm{~kJ} / \mathrm{kg}$ TS. The methane yield increase from 20 to 90 minutes may be attributed to the transformation of the particulate part of the substrate to more soluble substances by ultrasonication [28]. When high times of exposition (e.g., $180 \mathrm{~min}$.) are applied the opposite effect can be produced. The organic structures may get more complex owing to the polymeric matter released [13], becoming 


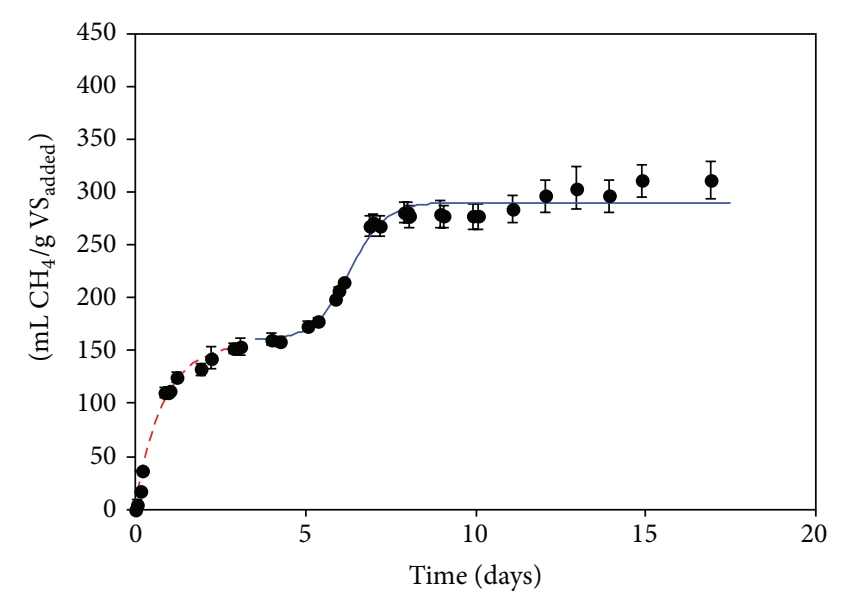

- US $20 \mathrm{~min}$

- - Exponential model

- Logistic model

FIGURE 1: Cumulative methane yield, expressed as $\mathrm{mLCH}_{4} / \mathrm{g}$ $\mathrm{VS}_{\text {added }}$, obtained during the BMP tests carried out with pretreated OMSW with ultrasound during 20 minutes.

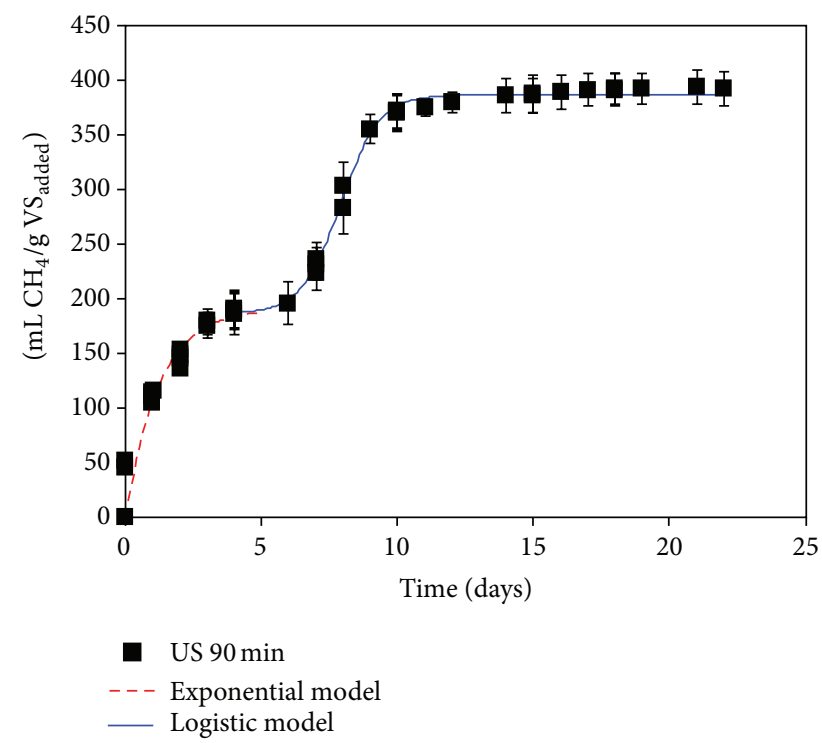

Figure 2: Cumulative methane yield, expressed as $\mathrm{mLCH}_{4} / \mathrm{g}$ $\mathrm{VS}_{\text {added }}$, obtained during the BMP tests carried out with pretreated OMSW with ultrasound during 90 minutes.

more difficult to biodegrade. Moreover, high intensive degree times of disintegration test have been found responsible for refractory compound formation and generation of soluble nonbiodegradable compounds which can inhibit methane production [11].

It has been recently demonstrated that the increased solubilization provoked by thermal and ultrasonic pretreatments on mixed-microalgal biomass was not followed by an increased methane production in BMP tests [31]. In the latter study the pretreatments enhanced the transformation of simple sugars to smaller carbon organic acids, especially

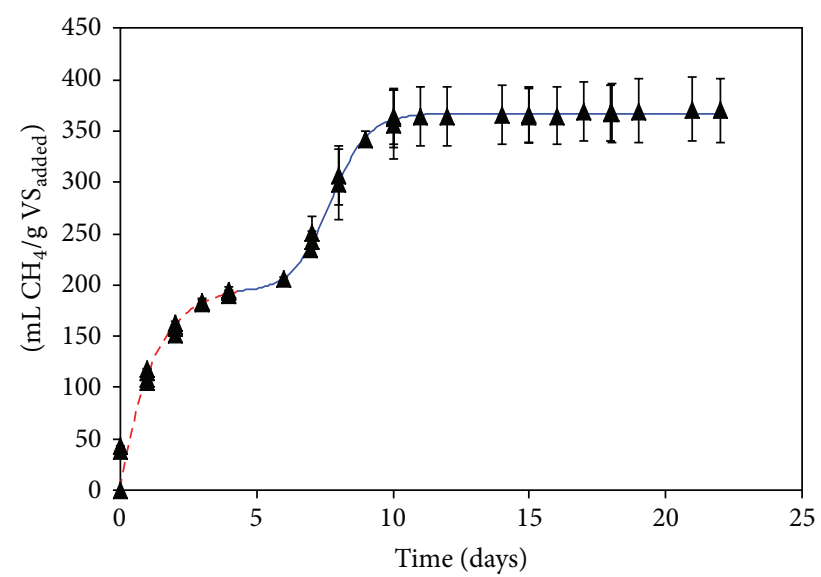

\ US $180 \mathrm{~min}$

- - - Exponential model

— Logistic model

Figure 3: Cumulative methane yield, expressed as $\mathrm{mLCH}_{4} / \mathrm{g}$ $\mathrm{VS}_{\text {added }}$, obtained during the BMP tests carried out with pretreated OMSW with ultrasound during 180 minutes.

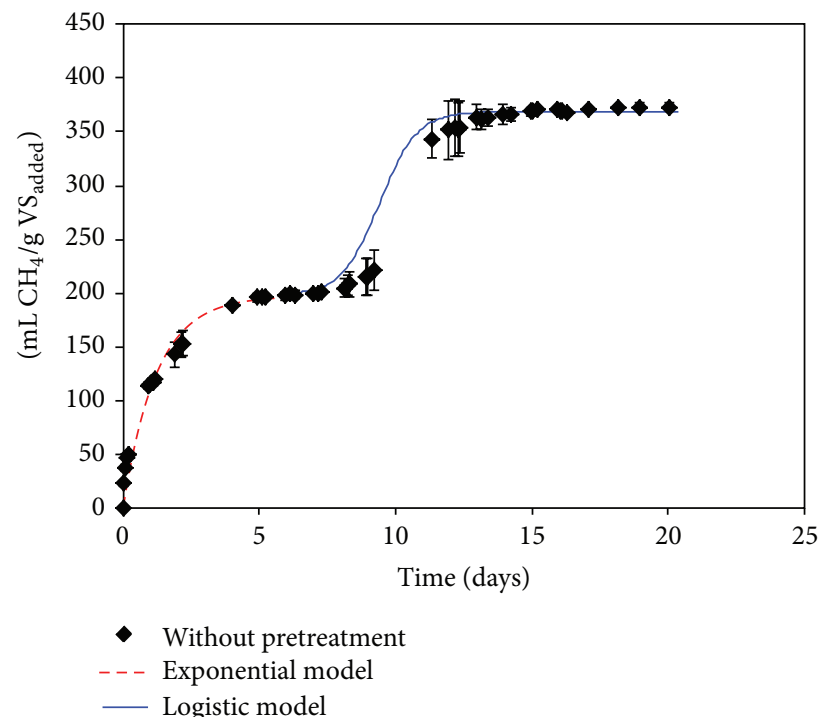

Figure 4: Cumulative methane yield, expressed as $\mathrm{mLCH}_{4} / \mathrm{g}$ $\mathrm{VS}_{\text {added }}$, obtained during the BMP tests carried out with untreated OMSW.

propionic acid, which results in inhibition of methanogenic microorganisms at certain concentrations [31]. Alzate et al. [32] have recently demonstrated the lack of correlation between the solubilization degree and methane enhancement potential in BMP tests of microalgae mixtures subjected to ultrasound pretreatment. They found no increases in methane productivity with increases in energy inputs at applied energies higher than $10.000 \mathrm{~kJ} / \mathrm{kg}$ TS.

3.3. Effect of Ultrasound Pretreatment on the Process Kinetics. Figures 1, 2, 3, and 4 show the evolution of methane production with time for ultrasonically pretreated two-phase 
TABLE 5: Kinetic parameters obtained from the exponential model in the BMP tests of untreated OMSW and ultrasound pretreated OMSW at 20, 90, and $180 \mathrm{~min}$.

\begin{tabular}{lcccc}
\hline $\begin{array}{l}\text { Time } \\
(\mathrm{min})\end{array}$ & $\begin{array}{c}B_{\max } \\
\left(\mathrm{mL} \mathrm{CH}_{4} / \mathrm{g} \mathrm{VS}_{\text {added }}\right)\end{array}$ & $\begin{array}{c}K \\
\left(\text { days }^{-1}\right)\end{array}$ & $R^{2}$ & S.E.E. \\
\hline Untreated OMSW & $197 \pm 4$ & $0.82 \pm 0.06$ & 0.97 & 11.3 \\
20 & $158 \pm 7$ & $1.21 \pm 0.14$ & 0.94 & 5.2 \\
90 & $191 \pm 11$ & $0.83 \pm 0.17$ & 0.92 & 12.2 \\
180 & $199 \pm 10$ & $0.83 \pm 0.16$ & 0.93 & 7.7 \\
\hline
\end{tabular}

$B_{\max }$ is the ultimate methane production; $K$ is the specific rate constant or apparent kinetic constant. Parameters from the nonlinear regression fit: $R^{2}$ : coefficient of determination; S.E.E.: standard error of estimate.

OMSW at 20, 90, and $180 \mathrm{~min}$ and untreated OMSW, respectively.

Two different stages were observed for all the cases studied: a first stage during the first 5-7 days of operation followed by an intermediate adaptation period or lag stage and finally a second stage, in which the methane production rate increased gradually to become almost zero at the 20-25 days of digestion.

In order to simulate the two stages observed, two different models were used and selected as previously by Rincón et al. [4] with thermally pretreated OMSW: a first-order exponential model for the first stage which is commonly applicable to easily biodegradable substrates [33] and a second sigmoidal or logistic model with its three characteristic phases, that is, lag, exponential increase, and final stabilization step [34].

3.3.1. First Phase: First-Order Exponential Model. The firstorder exponential model is given by the following expression:

$$
B_{1}=B_{\max } \cdot[1-\exp (-K \cdot t)],
$$

where $B_{1}\left(\mathrm{mLCH}_{4} / \mathrm{g} \mathrm{VS}\right.$ added $)$ is the cumulative specific methane production, $B_{\max }\left(\mathrm{mLCH}_{4} / \mathrm{g} \mathrm{VS}_{\text {added }}\right)$ is the ultimate methane production, $K$ is the specific rate constant or apparent kinetic constant $\left(\right.$ days $\left.^{-1}\right)$, and $t$ (days) is the time.

This model was applied for the first experimental stage of methane production or exponential step (from 0 to 5-7 days) for all the substrates tested. The adjustment by nonlinear regression of the pairs of experimental data $\left(B_{1}, t\right)$ using the Sigmaplot software (version 11.0) allowed the calculation of the parameters $K$ and $B_{\max }$ for this first stage of methane production (Table 5). The high values of the $R^{2}$ and the low values of the standard error of estimate (S.E.E.) for the cases tested demonstrate the goodness of the fit of experimental data to the model proposed for this first exponential stage.

Table 5 shows the specific rate constants $(K)$ obtained for the first stage of digestion (untreated two-phase OMSW and pretreated two-phase OMSWs at $200 \mathrm{~W}$ during 20, 90, and $180 \mathrm{~min}$ ) with values ranging between $0.82 \pm 0.06$ and $1.21 \pm$ 0.14 days $^{-1}$. $K$ was significantly higher for the ultrasound pretreatment at $20 \mathrm{~min}\left(K=1.21 \mathrm{~d}^{-1}\right)$ than for the other times studied. For the other pretreatment times studied, that is, 90 and $180 \mathrm{~min}$, and for the untreated OMSW, the $K$ values were practically similar ranging between 0.82 and $0.83 \mathrm{~d}^{-1}$. Therefore, the kinetic constant for the ultrasound pretreatment at 20 minutes was 46\% higher than those obtained for the pretreated OMSW at 90 and 180 minutes and $48 \%$ higher than for untreated OMSW. The highest value of

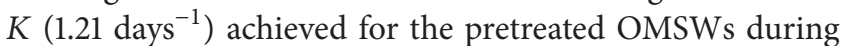
20 min might be associated with its lower lignin (14.4\%) and hemicellulose concentrations (10.9\%) after pretreatment compared to the other pretreatment conditions (Table 4). In addition, the values of the kinetic constants obtained in the present research work for the ultrasound pretreated OMSW at 90 and 180 minutes were of the same order of magnitude as those obtained in BMP tests of thermally treated OMSW at $180^{\circ} \mathrm{C}$ during 180 minutes [4].

During the first stage the ultimate methane production, $B_{\max }$, for the US $(20 \mathrm{~min})$ was somewhat lower $\left(158 \mathrm{~mL} \mathrm{CH}_{4} / \mathrm{g} \quad \mathrm{VS}_{\text {added }}\right)$ than those obtained for the other pretreatment times, whose value ranged between $191 \mathrm{mLCH}_{4} / \mathrm{g} \mathrm{VS}_{\text {added }}$ (US $90 \mathrm{~min}$ ) and $199 \mathrm{mLCH}_{4} / \mathrm{g}$ $\mathrm{VS}_{\text {added }}$ (US $180 \mathrm{~min}$ ). These results might indicate a slight increase of easily degradable compounds after 90 and 180 minutes of pretreatment but still with a high percentage of complex substrates diminishing the degradation rate.

\subsubsection{Second Phase: Sigmoidal or Logistic Model Application.} For the second stage of methane production, that is, between the 5th and 7th days and last day of the operating period, 25th day, the following logistic model (3) was used to estimate process performance $[4,33,34]$ :

$$
B_{2}=B_{0}+\frac{P}{\left[1+\exp \left(-4 \cdot R_{m} \cdot(t-\lambda) /(P+2)\right)\right]},
$$

where $B_{2}$ is the cumulative methane production during the second stage $\left(\mathrm{mL} \mathrm{CH}_{4} / \mathrm{g} \mathrm{VS}_{\text {added }}\right), B_{0}$ is the cumulative methane production at the startup of the second stage ( $\mathrm{mL} \mathrm{CH}_{4} / \mathrm{g} \mathrm{VS}_{\text {added }}$ ) and should approximately coincide with the value of $B_{\max }$ obtained at the end of the first stage, $P$ is the maximum methane production obtained in the second stage $\left(\mathrm{mLCH}_{4} / \mathrm{g} \mathrm{VS}_{\text {added }}\right), R_{m}$ is the maximum methane production rate $\left(\mathrm{mLCH}_{4} / \mathrm{g} \mathrm{VS}\right.$ added $\left.\mathrm{d}\right)$, and $\lambda$ is the lag time (days).

The logistic model assumes the rate of methane production to be proportional to microbial activity [35]. This model has been previously used for estimating the methane production in batch anaerobic digestion experiments of different substrates such as landfill leachate, herbaceous grass materials, and sewage sludge [33-36].

For the logistic model the maximum methane production obtained in the second stage $(P)$ had the maximum value for the 90-minute pretreatment $\left(200 \mathrm{mLCH}_{4} / \mathrm{g} \mathrm{VS}_{\text {added }}\right)$ followed by the 180 -minute pretreatment $\left(174 \mathrm{mLCH}_{4} / \mathrm{g}\right.$ $\left.\mathrm{VS}_{\text {added }}\right)$, untreated OMSW (171 $\left.\mathrm{mL} \mathrm{CH}_{4} / \mathrm{g} \mathrm{VS}_{\text {added }}\right)$, and pretreatment during 20 minutes $\left(130 \mathrm{mLCH}_{4} / \mathrm{g} \mathrm{VS}_{\text {added }}\right)$ (Table 6). Moreover, comparing the values of the $R_{m}$ or maximum methane production rates obtained in the logistic model (Table 6) the best pretreatment was the US (90 min). For the ultrasound pretreatment at 90 min the kinetics was the quickest; $70.5 \mathrm{~mL} \mathrm{CH}_{4} /\left(\mathrm{g} \mathrm{VS}_{\text {added }}\right.$-day) was produced, a value $12 \%$ higher than that obtained for untreated OMSW 
TABLE 6: Kinetic parameters obtained from the logistic model in the BMP tests of untreated OMSW and ultrasound pretreated OMSW at 20, 90 , and $180 \mathrm{~min}$.

\begin{tabular}{lccccc}
\hline $\begin{array}{l}\text { Time } \\
(\mathrm{min})\end{array}$ & $\begin{array}{c}B_{0} \\
\left(\mathrm{~mL} \mathrm{CH}_{4} / \mathrm{g} \mathrm{VS}_{\text {added }}\right)\end{array}$ & $\begin{array}{c}P \\
\left(\mathrm{~mL} \mathrm{CH}_{4} / \mathrm{g} \mathrm{VS}_{\text {added }}\right)\end{array}$ & $\begin{array}{c}R_{m} \\
\left(\mathrm{~mL} \mathrm{CH}_{4} / \mathrm{g} \mathrm{VS} \cdot \mathrm{d}\right)\end{array}$ & $\begin{array}{c}\lambda \\
(\text { days })\end{array}$ & $\begin{array}{c}R^{2} \\
\text { S.E.E. }\end{array}$ \\
\hline Untreated OMSW & $198 \pm 4$ & $171 \pm 4$ & 62.7 & $9.4 \pm 0.1$ & 0.99 \\
20 & $160 \pm 5$ & $130 \pm 55$ & 64.4 & $6.3 \pm 0.8$ & 0.96 \\
90 & $187 \pm 9$ & $200 \pm 9$ & 70.5 & $7.9 \pm 0.2$ & 0.99 \\
180 & $193 \pm 8$ & $174 \pm 8$ & 63.9 & $7.9 \pm 0.2$ & 0.99 \\
\hline
\end{tabular}

$B_{0}$ is the cumulative methane production at the startup of the second stage, $P$ is the maximum methane production obtained in the second stage, $R_{m}$ is the maximum methane production rate, and $\lambda$ is the lag time. Parameters from the nonlinear regression fit: $R^{2}$ : coefficient of determination; S.E.E.: standard error of estimate.

and $9.5 \%$ and $10.3 \%$ higher than that obtained at 20 and 180 minutes, respectively.

The ultrasound pretreatment during 90 minutes most likely promotes the release of more easily biodegradable compounds, which allowed an increase in the $R_{m}$ and a decrease in the lag period.

The shortest lag phase $(\lambda)$ was obtained for US (20 min), that is, 6.3 days, while the longest lag phase was achieved for the untreated OMSW, that is, 9.4 days. Long lag phases can lead to the generation of different inhibitor compounds that delay the startup of the second phase in the methane production [34]. The lowest $R_{m}$ value, that is, $62.7 \mathrm{~mL} \mathrm{CH}_{4} / \mathrm{g}$ $\mathrm{VS}_{\text {added }} \cdot \mathrm{d}$, was obtained for the pretreatment with the highest lag phase, that is, 9.4 days (untreated OMSW). This value of $R_{m}$ was very similar to that achieved in BMP tests of OMSW previously treated thermally at $180^{\circ} \mathrm{C}$ during $180 \mathrm{~min}$ [4].

The first derived $B_{2}$ with respect to the digestion time gives the evolution of the methane production rate with time during the second stage ( $\mathrm{mL} \mathrm{CH}_{4} /(\mathrm{g}$ VS-day)) (Figure 5). The degradation rate of ultrasound pretreated OMSW during 90 minutes was the fastest of the four conditions tested, achieving a maximum methane production rate $\left(R_{m}\right)$ of $70.5 \mathrm{~mL} \mathrm{CH}_{4} /(\mathrm{g} \mathrm{VS}$-day) after 7.9 days of digestion period. Although the maximum methane production rate for ultrasound pretreated OMSW for 20 minutes was somewhat lower (64.4 $\mathrm{mL} \mathrm{CH}_{4} /(\mathrm{g}$ VS -day)) than that mentioned for pretreated OMSW during 90 minutes, it was achieved at a lower time of 6.3 days. Finally, the methane production rate for untreated OMSW achieved the lowest $R_{m}$ value and it needed the highest time (9.4 days) to be reached.

Ultrasound pretreatment during 90 minutes gives the most promising results for a fast OMSW degradation process making available a large concentration of soluble and biodegradable components. Ultrasound pretreatment during 180 minutes had opposite effect, indicating a possible recalcitrant compound formation $[13,20]$.

3.4. Energy Balance. A net balance of the consumed energy in the pretreatment and the produced energy through BMP for the ultrasound pretreated OMSW was found to be negative for all pretreatment times and specific energies studied. The less unfavorable energy balance was observed for the lowest exposure time and specific energy studied, that is, 20 minutes, with a negative energy balance of $-1830 \mathrm{~kJ} / \mathrm{kg}$ TS. For pretreatments of 90 and 180 minutes the energy balance

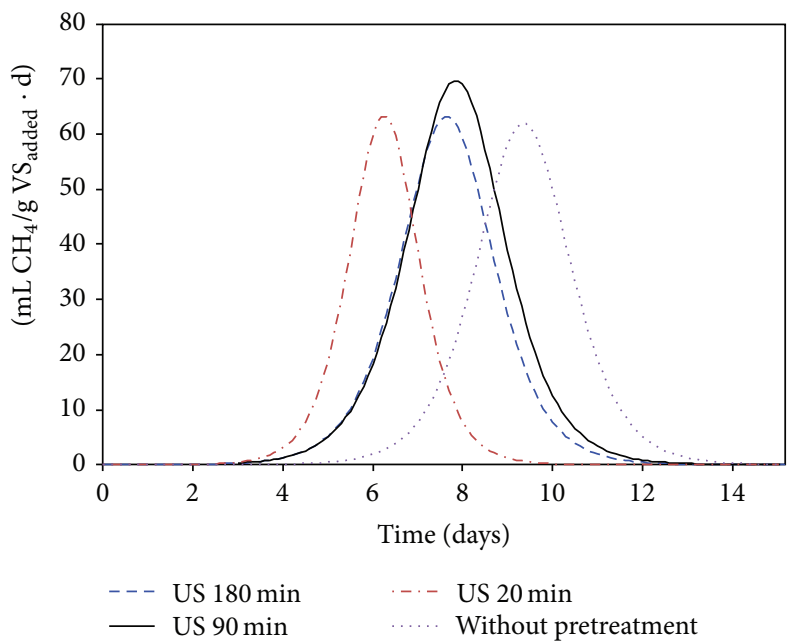

FIGURE 5: Methane production rate, expressed as $\mathrm{mL} \mathrm{CH}_{4} /(\mathrm{g} \mathrm{VS} \mathrm{d})$, obtained during the second stage of the BMP tests carried out with untreated OMSW and ultrasound pretreated OMSW during 20, 90, and 180 minutes.

between the consumed energy in the pretreatment (input energy) and produced energy through anaerobic digestion (output energy) was obviously more negative.

A similar negative energy balance has been recently reported in the evaluation of ultrasonic pretreatment combined with anaerobic digestion of mixed-microalgal biomass [31]. After applying thermal, ultrasonic, and alkali pretreatments to raw microalgae biomass to promote the anaerobic digestion efficiency through BMP tests it was observed that only the chemical pretreatment yielded slightly higher energy gains than that of nonpretreatment condition, while the energy balance with the ultrasonic pretreatment gave a negative value of $-220 \mathrm{~kJ} / \mathrm{kg}$ VS using a pretreatment time Of 180 seconds [31]. Houtmeyers et al. [37] reported that the pretreatment of WAS with ultrasounds and microwave both with energy specific of $2100 \mathrm{~kJ} / \mathrm{kg}$ sludge was economically not feasible although an increase in the biogas production of $27 \%$ (microwave pretreated) and 23\% (ultrasonic pretreated) was observed with respect to untreated samples. Likewise, a study of the effect of ultrasonic pretreatment 
on methane production potential from some corn ethanol products (distiller's wet grains, thin stillage, and condensed distiller's solubles) revealed that ultrasonic pretreatment required more energy than was generated by the process in terms of additional biogas production giving a negative energy balance [38]. The efficiency and economic viability of ultrasonication as a pretreatment method for hog manure anaerobic digestion was evaluated at specific energies of 250$30000 \mathrm{~kJ} / \mathrm{kg}$ TS [11]. Hog manure was found more amenable to ultrasonication than waste activated sludge, as it took only $3000 \mathrm{~kJ} / \mathrm{kg}$ TS to cause $15 \%$ more solubilization as compared to $25000 \mathrm{~kJ} / \mathrm{kg}$ TS for waste activated sludge. It was noted in this study that biomass cell rupture occurred at specific energy of $500 \mathrm{~kJ} / \mathrm{kg}$ TS. However, an economic evaluation indicated that only a specific energy of $500 \mathrm{~kJ} / \mathrm{kg}$ TS was economical, with a net energy output valued at $\$ 4.1 /$ ton of dry solids, due to a $28 \%$ increase in methane production [11].

\section{Conclusions}

Ultrasound pretreatment of two-phase OMSW at a power of $200 \mathrm{~W}$ (100\% amplitude) and a constant frequency of $24 \mathrm{kHz}$ during 20, 90, and 180 minutes increased the COD solubilization of this substrate compared to the untreated sample. The best methane yield obtained through BMP tests, $393 \mathrm{~mL} \mathrm{CH}_{4} / \mathrm{g} \mathrm{VS}_{\text {added }}$, was achieved for ultrasound pretreatment during $90 \mathrm{~min}$; this yield was 5.6\% higher than that obtained for OMSW without pretreatment. Moreover, taking into account the kinetics of the two stages observed during methane production (exponential and sigmoidal curves), the highest maximum methane production rate, $R_{m}$, was also achieved for ultrasound pretreatment during $90 \mathrm{~min}$. The maximum value of $R_{m}$ was found for ultrasound pretreatment during $90 \mathrm{~min}$, values $12 \%, 9.5 \%$, and $10.3 \%$ higher than that obtained for untreated OMSW and OMSW pretreated at 20 and $180 \mathrm{~min}$, respectively. A net balance between the consumed energy during the pretreatment and energy production through BMP gave a negative value for all the cases studied.

\section{Conflict of Interests}

The authors declare that there is no conflict of interests regarding the publication of this paper.

\section{Acknowledgments}

The authors wish to express their gratitude to the "Ministerio de Ciencia e Innovación” (Project CTM2011-25762/TECNO) and "Junta de Andalucía" for providing financial support. Dr. Rincón wishes to thank the Ramón y Cajal Program (RYC2011-08783 contract) from the Spanish Ministry of Economy and Competitiveness for providing financial support.

\section{References}

[1] J. Alba, F. J. Hidalgo, M. A. Ruiz et al., "Elaboración de aceite de oliva virgen," in El Cultivo del Olivo, D. Barranco, R. FernándezEscobar, and L. Rallo, Eds., pp. 551-588, Mundi-Prensa, Madrid, Spain, 2001.

[2] J. A. Alburquerque, J. Gonzálvez, D. García, and J. Cegarra, "Agrochemical characterisation of "alperujo", a solid by-product of the two-phase centrifugation method for olive oil extraction," Bioresource Technology, vol. 91, no. 2, pp. 195-200, 2004.

[3] R. Borja, B. Rincón, F. Raposo, J. Alba, and A. Martín, “A study of anaerobic digestibility of two-phases olive mill solid waste (OMSW) at mesophilic temperature," Process Biochemistry, vol. 38, no. 5, pp. 733-742, 2002.

[4] B. Rincón, L. Bujalance, F. G. Fermoso, A. Martín, and R. Borja, "Biochemical methane potential of two-phase olive mill solid waste: influence of thermal pretreatment on the process kinetics," Bioresource Technology, vol. 140, pp. 249-255, 2013.

[5] B. Rincón, L. Travieso, E. Sánchez et al., “The effect of organic loading rate on the anaerobic digestion of two-phase olive mill solid residue derived from fruits with low ripening index," Journal of Chemical Technology and Biotechnology, vol. 82, no. 3, pp. 259-266, 2007.

[6] B. Rincón, R. Borja, J. M. González, M. C. Portillo, and C. Sáiz-Jiménez, "Influence of organic loading rate and hydraulic retention time on the performance, stability and microbial communities of one-stage anaerobic digestion of two-phase olive mill solid residue," Biochemical Engineering Journal, vol. 40, no. 2, pp. 253-261, 2008.

[7] L. Appels, J. Lauwers, J. Degrve et al., "Anaerobic digestion in global bio-energy production: potential and research challenges," Renewable and Sustainable Energy Reviews, vol. 15, no. 9, pp. 4295-4301, 2011.

[8] T. Shimizu, K. Kudo, and Y. Nasu, "Anaerobic waste-activated sludge digestion-a bioconversion mechanism and kinetic model," Biotechnology and Bioengineering, vol. 41, no. 11, pp. 1082-1091, 1993.

[9] A. Tiehm, K. Nickel, and U. Neis, "The use of ultrasound to accelerate the anaerobic digestion of sewage sludge," Water Science and Technology, vol. 36, no. 11, pp. 121-128, 1997.

[10] M. Saha, C. Eskicioglu, and J. Marin, "Microwave, ultrasonic and chemo-mechanical pretreatments for enhancing methane potential of pulp mill wastewater treatment sludge," Bioresource Technology, vol. 102, no. 17, pp. 7815-7826, 2011.

[11] E. Elbeshbishy, S. Aldin, H. Hafez, G. Nakhla, and M. Ray, "Impact of ultrasonication of hog manure on anaerobic digestability," Ultrasonics Sonochemistry, vol. 18, no. 1, pp. 164-171, 2011.

[12] A. Elliott and T. Mahmood, "Pretreatment technologies for advancing anaerobic digestion of pulp and paper biotreatment residues," Water Research, vol. 41, no. 19, pp. 4273-4286, 2007.

[13] S. Pilli, P. Bhunia, S. Yan, R. J. LeBlanc, R. D. Tyagi, and R. Y. Surampalli, "Ultrasonic pretreatment of sludge: a review," Ultrasonics Sonochemistry, vol. 18, no. 1, pp. 1-18, 2011.

[14] H. Carrère, C. Dumas, A. Battimelli et al., "Pretreatment methods to improve sludge anaerobic degradability: a review," Journal of Hazardous Materials, vol. 183, no. 1-3, pp. 1-15, 2010.

[15] A. Tiehm, K. Nickel, M. Zellhorn, and U. Neis, "Ultrasonic waste activated sludge disintegration for improving anaerobic stabilization," Water Research, vol. 35, no. 8, pp. 2003-2009, 2001. 
[16] C. Bougrier, H. Carrère, and J. P. Delgenès, "Solubilisation of waste-activated sludge by ultrasonic treatment," Chemical Engineering Journal, vol. 106, no. 2, pp. 163-169, 2005.

[17] F. Hogan, S. Mormede, P. Clark, and M. Crane, "Ultrasonic sludge treatment for enhanced anaerobic digestion," Water Science and Technology, vol. 50, no. 9, pp. 25-32, 2004.

[18] E. Gonze, S. Pillot, E. Valette, Y. Gonthier, and A. Bernis, "Ultrasonic treatment of an aerobic activated sludge in a batch reactor," Chemical Engineering and Processing: Process Intensification, vol. 42, no. 12, pp. 965-975, 2003.

[19] T. B. El-Hadj, J. Dosta, R. Márquez-Serrano, and J. MataÁlvarez, "Effect of ultrasound pretreatment in mesophilic and thermophilic anaerobic digestion with emphasis on naphthalene and pyrene removal," Water Research, vol. 41, no. 1, pp. 8794, 2007.

[20] L. L. Zhang, X. X. Feng, N. W. Zhu, and J. M. Chen, "Role of extracellular protein in the formation and stability of aerobic granules," Enzyme and Microbial Technology, vol. 41, no. 5, pp. 551-557, 2007.

[21] U. Nels, K. Nickel, and A. Tiehm, "Enhancement of anaerobic sludge digestion by ultrasonic disintegration," Water Science and Technology, vol. 42, no. 9, pp. 73-80, 2000.

[22] APHA-AWWA-WPCF, Standard Methods for the Examination of Water and Wastewater, APHA-AWWA-WPCF, Washington, DC, USA, 20th edition, 1998.

[23] P. J. Van Soest, J. B. Robertson, and B. A. Lewis, "Methods for dietary fiber, neutral detergent fiber, and nonstarch polysaccharides in relation to animal nutrition," Journal of Dairy Science, vol. 74, no. 10, pp. 3583-3597, 1991.

[24] J. Kim, C. Park, T. Kim et al., "Effects of various pretreatments for enhanced anaerobic digestion with waste activated sludge," Journal of Bioscience and Bioengineering, vol. 95, no. 3, pp. 271275, 2003.

[25] H. Carrère, B. Sialve, and N. Bernet, "Improving pig manure conversion into biogas by thermal and thermo-chemical pretreatments," Bioresource Technology, vol. 100, no. 15, pp. 36903694, 2009.

[26] Q. Wang, M. Kuninobu, K. Kakimoto, H. I. Ogawa, and Y. Kato, "Upgrading of anaerobic digestion of waste activated sludge by ultrasonic pretreatment," Bioresource Technology, vol. 68, no. 3, pp. 309-313, 1999.

[27] C. González-Fernández, B. Sialve, N. Bernet, and J. P. Steyer, "Comparison of ultrasound and thermal pretreatment of Scenedesmus biomass on methane production," Bioresource Technology, vol. 110, pp. 610-616, 2012.

[28] V. Fernández-Cegrí, M. A. de la Rubia, F. Raposo, and R. Borja, "Impact of ultrasonic pretreatment under different operational conditions on the mesophilic anaerobic digestion of sunflower oil cake in batch mode," Ultrasonics Sonochemistry, vol. 19, no. 5, pp. 1003-1010, 2012.

[29] C. Bougrier, C. Albasi, J. P. Delgenès, and H. Carrère, "Effect of ultrasonic, thermal and ozone pre-treatments on waste activated sludge solubilisation and anaerobic biodegradability," Chemical Engineering and Processing, vol. 45, no. 8, pp. 711-718, 2006.

[30] G. Erden and A. Filibeli, "Ultrasonic pre-treatment of biological sludge: consequences for disintegration, anaerobic biodegradability, and filterability," Journal of Chemical Technology and Biotechnology, vol. 85, no. 1, pp. 145-150, 2010.
[31] S. Cho, S. Park, J. Seon, J. Yu, and T. Lee, "Evaluation of thermal, ultrasonic and alkali pretreatments on mixedmicroalgal biomass to enhance anaerobic methane production," Bioresource Technology, vol. 143, pp. 330-336, 2013.

[32] M. E. Alzate, R. Muñoz, F. Rogalla, F. Fdz-Polanco, and S. I. Pérez-Elvira, "Biochemical methane potential of microalgae: influence of substrate to inoculum ratio, biomass concentration and pretreatment," Bioresource Technology, vol. 123, pp. 488494, 2012.

[33] L. Li, X. Kong, F. Yang, D. Li, Z. Yuan, and Y. Sun, "Biogas production potential and kinetics of microwave and conventional thermal pretreatment of grass," Applied Biochemistry and Biotechnology, vol. 166, no. 5, pp. 1183-1191, 2012.

[34] A. Donoso-Bravo, S. I. Pérez-Elvira, and F. Fdz-Polanco, "Application of simplified models for anaerobic biodegradability tests. Evaluation of pre-treatment processes," Chemical Engineering Journal, vol. 160, no. 2, pp. 607-614, 2010.

[35] L. Altaş, "Inhibitory effect of heavy metals on methaneproducing anaerobic granular sludge," Journal of Hazardous Materials, vol. 162, no. 2-3, pp. 1551-1556, 2009.

[36] S. Pommier, D. Chenu, M. Quintard, and X. Lefebvre, "A logistic model for the prediction of the influence of water on the solid waste methanization in landfills," Biotechnology and Bioengineering, vol. 97, no. 3, pp. 473-482, 2007.

[37] S. Houtmeyers, L. Appels, J. Degrève, J. V. Impe, and R. Dewil, "Comparing the influence of ultrasonic and microwave pretreatment on the solubilization and semi-continuous digestion of waste activated sludge," in Proceedings of the Anaerobic Digestion Conference, Paper SPC21, Santiago de Compostela, Spain, June 2013.

[38] W. Wu-Haan, R. T. Burns, L. B. Moody, C. J. Hearn, and D. Grewell, "Effect of ultrasonic pretreatment on methane production potential from corn ethanol coproducts," Transactions of the ASABE, vol. 53, no. 3, pp. 883-890, 2010. 